\title{
Community food systems: Strengthening the research-to-practice continuum
}

\author{
David C. Campbell ${ }^{a *}$ \\ Department of Human and Community Development, University of California, Davis \\ Ildi Carlisle-Cummins ${ }^{\text {b }}$ \\ Department of Human and Community Development, University of California, Davis
}

Gail Feenstra $^{\mathrm{c}}$

Sustainable Agriculture Research and Education Program, University of California, Davis

Submitted September 17, 2012 / Revised January 15 and February 25, 2013 / Accepted February 25, 2013 /

Published online June 17, 2013

Citation: Campbell, D. C., Carlisle-Cummins, I., \& Feenstra, G. (2013). Community food systems: Strengthening

the research-to-practice continuum. Journal of Agriculture, Food Systems, and Community Development, 3(3), 121-138.

http://dx.doi.org/10.5304/jafscd.2013.033.008

Copyright (C) 2013 by New Leaf Associates, Inc.

\begin{abstract}
Growing public interest in links between food, health, and the environment has sparked exponential growth in local and regional food system projects. Along with local experimentation has come an accompanying surge in related academic
\end{abstract}

\footnotetext{
a* Corresponding author: Department of Human and Community Development, UC Davis, 1 Shields Avenue, Davis, California 95616 USA; dave.c.campbell@ucdavis.edu

b 1 Shields Avenue, Davis, California 95616 USA; icarlislecummins@ucdavis.edu

c1 Shields Avenue, Davis, California 95616 USA; gwfeenstra@ucdavis.edu
}

Note: An earlier version of this paper was presented at the annual meeting of the Rural Sociological Society, July 26-29, 2012, Chicago. research. Are we learning what we need to know to expand the impact of the work? This paper introduces a new community food systems bibliography as a tool to help build usable knowledge. Drawing on a set of literature reviews prepared by students in a University of California Davis graduate seminar, we illustrate how the bibliography can facilitate literature scans to begin to identify persistent and strategic challenges facing community food system practitioners. Our analysis of the student reviews finds three interrelated challenges: (1) an economic challenge rooted in the difficulty of finding price points that work for farmers while ensuring that low-income consumers have access to healthy food and food system workers have decent wages and benefits; (2) a social challenge to confront racial and class bias while forging practical solutions; and (3) a political challenge of reconciling "insider" and 
"outsider" strategies, the former emphasizing incremental reform and the latter systemic change. These challenges resist simple solutions, but progress can be made if researchers and practitioners join forces. We discuss the potential for conceptual frameworks drawn from the applied fields of community development and public policy to inform the needed dialog between theory and practice.

\section{Keywords}

bibliography, community development, community food systems, food policy, food systems literature review, local food, local food systems, regional food systems, sustainable agriculture

\section{Introduction}

Growing public interest in links between food, health, and the environment has sparked exponential growth in local and regional food system projects. The specific projects vary widely in their focus, scope, and motivation. Although many efforts are modest and initiated in response to specific community needs, when viewed collectively the projects are contributing to a broadbased social and economic experiment in how to build food economies that are more locally based and increasingly self-reliant. At issue is whether and how we can move closer to the vision of a community food system in which sustainable food production, processing, distribution, and consumption are integrated to enhance the economic, environmental, and social health of a particular place (Feenstra, 2002).

Along with local experimentation has come an accompanying surge in related academic research. With tremendous growth both in on-the-ground activity and academic reflection, we would hope to find strong, mutually enhancing linkages between research and practice. Local food system practitioners, ideally, would gain information and assessments to guide their strategies and activities. Researchers looking across local settings would gain a better sense of practical challenges being encountered and opportunities seized, shaping their research agendas accordingly. Reality, however, often falls short of this ideal two-way engagement. Bridging the gap requires intentionally bringing research and practice into better alignment.

Animated by a desire to bring researchers and practitioners into fruitful conversation, a University of California Davis (UC Davis) research team began to compile, organize, and analyze the large body of community food systems research literature into a bibliography. ${ }^{1}$ The bibliography was designed to be a tool to aid researchers in identifying potential research topics, questions, and current literature in the field. We hoped it would help focus questions that inform graduate students and other researchers as they contribute to the research-to-practice continuum. For example, do we know enough to say whether particular local strategies and approaches are working or not working, and why? What research topics need more attention? How effectively are we organizing research projects to learn across local cases? What creative changes are local practitioners forging in response to academic advice and critique? Likewise, what new topics are researchers tackling in response to stated needs of practitioners? It is a propitious time to be asking these and related questions, as local experimentation and academic work in this field take deeper root.

Definitive answers to any of the above questions are beyond the scope of this paper. Instead, we will (1) introduce the bibliography as a research tool, noting the methods by which it was constructed, assumptions it makes, and associated limitations; (2) illustrate how the bibliography might be used to generate important questions for academic analysis and local experimentation; and (3) offer suggestions about how academics and practitioners might join forces to puzzle through persistent challenges facing the field. Our analysis and discussion are preliminary and open-ended, intended to promote further inquiry by raising key issues rather than settling well-established questions. Indeed,

\footnotetext{
1 The bibliography was compiled in 2011 by a graduate student researcher, Courtney Marshall, under the direction of UC Davis researchers David Campbell, Gail Feenstra, and Ryan Galt. Pending resource availability, we hope to update it annually. So that it might be used by researchers and practitioners, the bibliography is publicly available; it can be downloaded in any of three formats (PDF, Excel, Endnote), depending on the needs of users, at: http://www.sarep.ucdavis.edu/sfs/CFSresources
} 
our experience with the bibliography project has been humbling. We encountered greater than expected difficulties assembling and then categorizing the large, wide-ranging, and quickly expanding literature. And if our preliminary reviews of some of the literature are a good indication, it will be even more difficult to take the additional step of discerning evidence-based lessons for practice or a focused research agenda. Still, even small, tentative steps toward these ends are worth taking.

\section{Approach and Methods}

\section{Constructing the Community Food Systems Bibliography}

While noting the lack of clear boundaries in this field of study, we sought out academic articles that dealt with one or more projects, processes, institutions, or other elements frequently associated with the idea of community food systems. The focus was on collaborative efforts that seek to benefit a particular, geographically bounded place or region and are concerned with enhancing the environmental, economic, and/or social impacts of the food system. We limited our scope by excluding articles whose sole or predominant focus was how food is grown (agricultural production practices) as well as articles that focused on food issues in global south settings. Most articles we selected analyze activities and trends within the United States, although some articles from and about Europe and some parts of Asia are included. Targeting primarily work published since 2000 in peer-reviewed journals, but including some seminal research published prior to that, we compiled relevant literature using three main approaches:

- reading through every issue of leading journals in the field since 2000 and scanning the abstracts of all their research articles, including Community Development, Rural Sociology, Agriculture and Human V alues, Journal of Environmental Hunger \& Nutrition, Renewable Agriculture and Food Systems (formerly American Journal of Alternative Agriculture), and Journal of Agriculture, Food Systems, and Community Development;

- using key search terms in Google Scholar and the Web of Science database; and
- consulting reading lists from UC Davis food system classes and bibliographies.

Beginning with categories drawn from the authors' knowledge of the field, we categorized the literature by key topics. As new articles accumulated, we revisited the list of categories in an iterative fashion, adding new topics when it seemed warranted, reconsidering whether and how various topics might be lumped together, and looking for ways to name broad analytic categories under which specific topics might be listed.

Eventually, we grouped the various subtopics into four overarching categories: (1) underlying definitions and assumptions; (2) strategies linking production, marketing, and consumption; (3) institutional supports; and (4) ethical concerns and social-justice issues. The final categorization scheme is included in table 1 .

Because the categorization scheme changed somewhat during the search process, many articles added to the bibliography early in the process needed to be recategorized after our category list was finalized. In addition, some articles originally included needed to be culled. The latter occurred because our inclusion parameters were deliberately broad early in the process, and grew more refined as the work continued. The team read the abstract of each article and often skimmed the body of the article if it was deemed necessary to get a better idea of whether to include the article and, if so, how to most properly categorize it.

Three important caveats should be kept in mind. First, any categorization scheme of a literature this wide-ranging is bound to be somewhat arbitrary. Having gone through many potential schemes before settling on this one, we appreciate that there are alternatives. Second, despite our efforts to be systematic in compiling the bibliography, we recognize that this product is not complete or fully comprehensive. The volume of work published on this topic has increased exponentially in recent years, and new work appears frequently. Third, the key role played by systems thinking in this field makes it difficult to generate discrete analytical categories and to use them to label the content of individual articles. Our working procedure has been to assign any particular article to up 
to three subcategories, based in the majority of cases on examining only the title and abstract. This is at best an approximate method. We see it as a starting point for students and scholars working on particular topics, from which they can launch more thorough reviews.

\section{Exploring the Analytic} Uses of the Bibliography During fall 2011, the authors were part of a graduate seminar in which students prepared literature reviews on topics of their choice from among the subcategories in the bibliography. Driven by interests of the 15 enrolled students, many of whom had previous on-the-ground experience in local food systems work, these topics included: assumptions about the constraints and opportunities posed by conventional systems; labor and farmworkers; race, ethnicity, gender, and class; food security and food justice; local food systems and social movements; consumer behavior and demand; values-based supply chains; community gardens; energy and environment; and tapping local knowledge and networks. Subsequent independent study by additional students examined the topics of land tenure and beginning farmers; city and regional planning and foodshed planning; and economic benefits of community food systems. Since a few students chose to work on the same topic, the

\section{Table 1. Outline of Categories and Subcategories in} Community Food Systems Bibliography

\section{DEFINITIONS AND ASSUMPTIONS}

A. Definitions of regional/local/sustainable food systems

B. Assumptions about constraints/opportunities posed by conventional systems

II. STRATEGIES LINKING PRODUCTION, MARKETING, AND CONSUMPTION

A. Economic and business development

1. Consumer behavior/demand

2. Direct marketing

a. Community supported agriculture (CSAs)

b. Farmers' markets

c. Farm stands

d. Farm to restaurant

e. Farm to institution

3. Regional food systems marketing (campaigns, branding, etc.)

4. Venues for local foods processing and distribution

5. Economic benefits of regional food systems

6. Agritourism

7. Values-based supply chains

B. Gardens

1. School gardens

2. Home gardens

3. Community gardens

C. Urban farms

D. Civic agriculture

E. Changing cultural values around food consumption

F. Energy and environment

1. Waste/recycling

2. Food miles

III. INSTITUTIONAL SUPPORTS

A. Regional food systems planning

1. City and regional planning and/or foodshed planning

a. Community food system assessments/local food system indicators

b. Farmland preservation

B. Policies, regulations, and governance mechanisms or processes

1. Local (including food policy councils)

2. State/regional

3. Federal (farm bill, etc.)

C. Education and training

1. The university's role (e.g. student farms, university curriculum, and faculty research/public scholarship)

2. Training programs

3. Tapping local knowledge/networks for sharing ideas, learning

4. Nutrition education

\section{ETHICAL CONCERNS AND SOCIAL JUSTICE ISSUES}
A. Labor
B. Race/ethnicity/gender/class
C. Food security/justice
D. Local control/democracy
E. Social movements
F. Critique of localism 
reviews ended up addressing 13 of the 41 subtopics identified in the bibliography, with varying degrees of literature coverage. Table 2 reports the number and percentage of articles in the total bibliography $(\mathrm{N}=1,598)$ that we read and analyzed, by individual subtopic. Figure 1 shows the percentages of the articles reviewed for this paper $(n=501)$ that came from each of the four main categories of the bibliography.

During the seminar, students were asked to present the findings from their literature reviews. As part of that assignment, they were asked to address whether the research had reached any common conclusions about which local strategies, approaches, or activities were succeeding and which were not. Without exception, they reported that the literature provided little evidence to support definitive statements of this type. This finding is perhaps not too surprising given that (1) many students selected topics that featured more theoretical articles and fewer devoted to specific strategies and practices in communities, and (2) each student reviewed in depth a relatively small number of articles on their topic (approximately 25-30). The students also found that much of the literature consists of microscale case histories with insufficient attention to middle-range conceptual frameworks by which the individual cases could be

\section{Table 2. Count and Percentage of Articles Reviewed Within Each Category and Subcategory (out of all articles in the bibliography)}

\begin{tabular}{|c|c|c|}
\hline $\begin{array}{l}\text { Category } \\
\text { Subcategory }\end{array}$ & $\begin{array}{c}\text { Number of } \\
\text { Articles Reviewed } \\
\text { (Total articles in category) }\end{array}$ & $\begin{array}{c}\text { Percentage of } \\
\text { Articles Reviewed }\end{array}$ \\
\hline Definitions and Assumptions & $31(162)$ & $19 \%$ \\
\hline $\begin{array}{l}\text { Assumptions about constraints and opportunities posed by } \\
\text { conventional systems }\end{array}$ & $28(79)$ & $35 \%$ \\
\hline Definitions of regional, local, and sustainable food systems & $3(83)$ & $4 \%$ \\
\hline Ethical Concerns and Social-Justice Issues & $168(562)$ & $30 \%$ \\
\hline Food security and food justice & $70(115)$ & $61 \%$ \\
\hline Race, ethnicity, gender, class & $50(203)$ & $25 \%$ \\
\hline Local food systems and social movements & $27(92)$ & $29 \%$ \\
\hline Labor and farmworkers & $21(21)$ & $100 \%$ \\
\hline All other subcategories in this category (see table 1) & $0(131)$ & $0 \%$ \\
\hline Strategies Linking Production, Marketing, and Consumption & $254(1,551)$ & $16 \%$ \\
\hline Values-based supply chains & $117(117)$ & $100 \%$ \\
\hline Community gardens & $48(110)$ & $44 \%$ \\
\hline Economic benefits of regional food systems & $36(114)$ & $32 \%$ \\
\hline Energy and environment & $28(47)$ & $60 \%$ \\
\hline Consumer behavior and demand & $25(177)$ & $14 \%$ \\
\hline All other subcategories in this category (see table 1 ) & $0(986)$ & $0 \%$ \\
\hline Institutional Supports & $48(773)$ & $6 \%$ \\
\hline $\begin{array}{l}\text { Education: Tapping local knowledge and networks for sharing ideas, } \\
\text { learning }\end{array}$ & $21(154)$ & $14 \%$ \\
\hline City and regional planning and/or foodshed planning & $16(91)$ & $18 \%$ \\
\hline$\overline{\text { Farmland preservation }}$ & $11(11)$ & $100 \%$ \\
\hline All other subcategories in this category (see table 1) & $0(517)$ & $0 \%$ \\
\hline TOTAL (using unduplicated count) a & $501(1,598)$ & $31 \%$ \\
\hline
\end{tabular}

a The number of articles in the cells represent the total number of articles reviewed in each category or subcategory. Because each article could be coded into up to 3 subcategories, the total unduplicated count of articles in the entire bibliography $(1,598)$ is lower than the count one would get by totaling the categories in this table $(3,048)$. 
compared to deepen insight. A more thorough review of the literature than we have conducted to date would be needed to validate this initial impression.

For the analysis presented in this paper, we asked ourselves a different question, wondering whether the student literature reviews identified issues, questions, or challenges worthy of more attention by researchers and practitioners. That work began during the seminar, as the class heard and discussed presentations on the literature reviews. It continued when the authors read and reread the written student literature reviews, taking careful notes. While the individual reviews identified many themes and issues, most were specific to literature in particular subcategories. By contrast, three interrelated but distinct strategic challenges stood out as having surfaced in five or more reviews (table 3):

- an economic challenge of finding price points that work for multiple
Figure 1. Of the 501 Articles Reviewed for This Paper, the Percentage That Came from Each of the Four Main Categories of the Bibliography

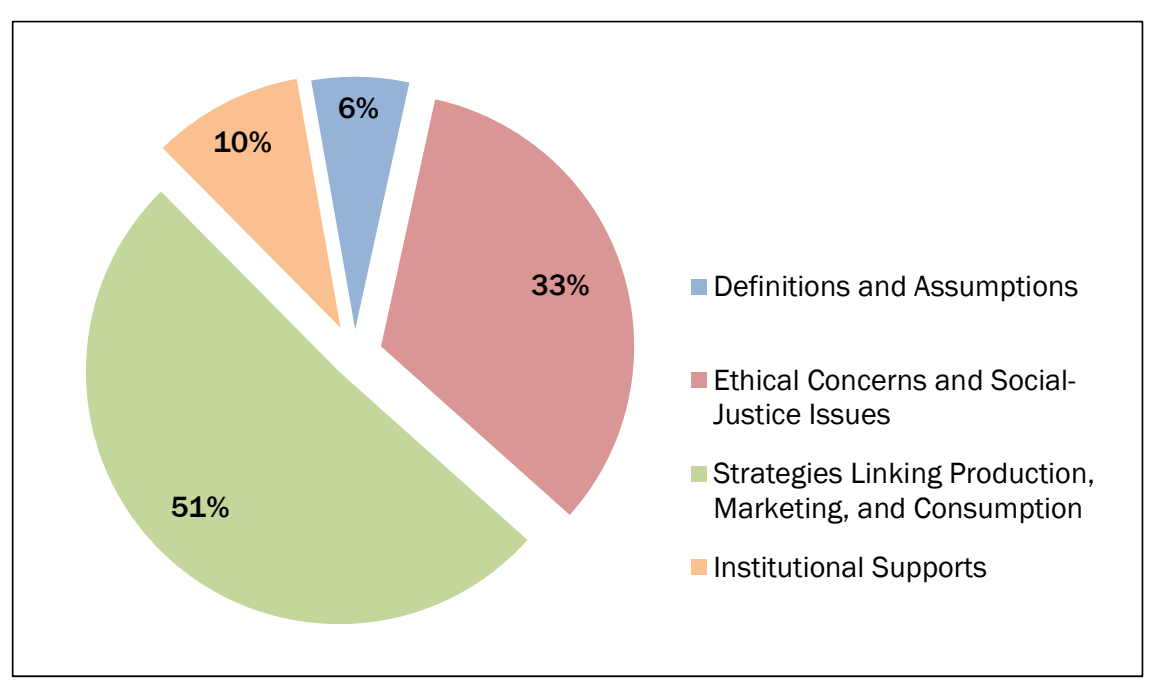

constituencies (addressed in 5 of 13 subcategories reviewed);

- a social challenge to confront racial and class bias while forging practical solutions (addressed in 9 of 13 subcategories reviewed);

- a political challenge of reconciling "insider" and "outsider" change strategies (addressed in 8 of 13 subcategories reviewed).

Table 3. Strategic Challenges Identified in Five or More Student Literature Reviews (by subcategories)

\begin{tabular}{|c|c|c|c|}
\hline Subcategory Reviewed & $\begin{array}{l}\text { Economic } \\
\text { Challenge }\end{array}$ & $\begin{array}{l}\text { Social } \\
\text { Challenge }\end{array}$ & $\begin{array}{l}\text { Political } \\
\text { Challenge }\end{array}$ \\
\hline $\begin{array}{l}\text { Assumptions about constraints and opportunities posed by } \\
\text { conventional systems }\end{array}$ & & & $x$ \\
\hline City and regional planning and foodshed planning & & & $x$ \\
\hline Community food security and food justice & $x$ & $x$ & $x$ \\
\hline Community gardens & & $x$ & \\
\hline Consumer behavior and demand & $x$ & $x$ & \\
\hline Economic benefits of regional food systems & $\mathrm{X}$ & $x$ & \\
\hline Education: Tapping local knowledge networks & & $x$ & \\
\hline Energy and the environment & & $x$ & \\
\hline Farmland preservation & & & $x$ \\
\hline Labor and farmworkers & $x$ & $x$ & $\mathrm{X}$ \\
\hline Local food systems and social movements & & $x$ & $x$ \\
\hline Race and food justice & $X$ & $\mathrm{X}$ & $X$ \\
\hline Values-based supply chains & & & $X$ \\
\hline
\end{tabular}


Having the bibliography as a tool made it possible to scan a wider range of literature than is typical in most literature reviews, which often focus on a single topic. This broader scan in turn revealed cross-cutting challenges that appear with some regularity. The following section describes what we learned about these challenges, drawing on evidence from the literature that students reviewed. We offer them as illustrative of the potential uses of the bibliography to provide greater analytic focus for research and practice, and in hopes they may be further refined by subsequent metaanalyses. While we discuss the three challenges separately to underscore their unique dimensions, in everyday practice they interact in complex ways, making easy solutions elusive.

\section{Strategic Challenges in Community Food Systems Work}

Below we describe the three strategic challenges identified by the student reviews, drawing on the literature to illustrate various ways these challenges are framed by academics and practitioners.

\section{Economic challenge: Dealing with the promise and limits of markets}

Perhaps no institution is more associated with community food systems than the farmers' market. The growth in the number of farmers' markets over recent decades might be used as a proxy indicator for growing public interest in local and regional food. But while markets are a necessary part of the solution, there are numerous indications in our literature reviews that private enterprise alone is insufficient by itself to achieve key community food system values, such as equity, sustainability, and democracy. Research points to the need to supplement market-based solutions with carefully targeted public investments (Allen, 2010; Campbell \& Feenstra, 2001) in order to offset two market dynamics.

Market challenge 1: Finding price points that work for farmers while ensuring low-income consumers have access to healthy food. Many low-income communities are isolated from access to healthy food options (Algert, Agrawal, \& Lewis, 2006; Block \& Kouba, 2006), leading to efforts to expand access. Research shows that disparities lead certain populations to experience diet-related chronic disease, deficient cognitive development, and poor educational attainment (Murphy \& Smith, 2009; Seligman \& Schillinger, 2010). Among the remedial alternatives discussed in the literature are gardening and nutrition education (Lautenschlager \& Smith, 2007; Meehan, Yeh, \& Spark, 2008), increasing enrollment in food assistance programs (e.g. WIC and SNAP) and use of government assistance programs at farmers' markets (Grace, Grace, Becker, \& Lyden, 2008), as well as other efforts to improve access to and availability of fresh, healthy food (Munoz-Plaza, Filomena, \& Morland, 2008; Ohri-Vachaspati, Masi, Taggart, Konen, \& Kerrigan, 2009). At least potentially, some of these efforts might also benefit small to medium-scale farmers looking for alternative marketing outlets.

Marshall's paper on community food security concludes: "The literature reviewed shows the difficulty of both supporting food security and small scale local farmers" (2011, p. 22; see also Allen, 1999; Baker, 2003; Guthman, Morris, \& Allen, 2006; Johnston \& Baker, 2005). Even organizations whose leaders deeply believe in both these goals have a hard time achieving them simultaneously (Johnston \& Baker, 2005). McEntee (2010) describes the uneasy relationship between the needs of food producers to have better income and the needs of food "consumers" to have affordable and equitable access to healthy food. Alkon (2008b) demonstrates the difficulties in a case study of a West Oakland market that struggles to both attract local residents and support the vendors, many of whom have left due to the limited economic benefits. Interviews with farmers' market managers show that some markets prioritize farmers' income over food security, while markets that prioritize food security understandably have trouble convincing farmers to continue to sell at their market (Alkon, 2008a; Guthman et al., 2006). Marshall notes, "Despite the best intentions, it is difficult to find a price point that meets the needs of both small-scale farmers and a diverse group of consumers" (2011, p. 22). Tensions such as this will no doubt persist as long as we experience an economic system that leaves many without sufficient resources to buy food and in which less 
healthy food products benefit from substantial public subsidies.

Market challenge 2: Finding price points that work for farmers while ensuring just pay and working conditions for farmworkers and other food system employees. ${ }^{2}$ A distinct but related lens on economic issues (and in turn race and class) involves labor, focusing on pay and working conditions for those who are employed to grow, harvest, process, market, distribute, and serve food. Since its inception, the sustainable agriculture movement has included activists motivated by concerns for farmworkers, but it has also been critiqued by those who do not feel the movement is making enough progress in addressing farm or food system labor issues (Food Chain Alliance, 2012). Proponents of community food systems initiatives experience this same tension on a broader scale since the focus includes workers across the food system, such as those in food-processing industries, in addition to workers in the field.

Among the motivations for relocalization of food is the preservation of small and medium-scale family farms. Yet this motive runs up against some evidence suggesting there are better working conditions for farm labor on large farms than on smaller, organic farms (Shreck, Getz, \& Feenstra, 2006). Because of this, some observers view the romantic image of small farms as "an incomplete and unsatisfactory entry into issues of fairness and justice in local food systems" (Hinrichs \& Allen, 2008 , p. 348). The larger point is that all farmers big or small, organic or conventional, locally oriented or global - participate in the same economic system and face strong pressures to reduce labor costs. The U.S. agriculture system is embedded within the greater economic capitalistic system, which seeks to lower labor costs for greater economic profit. At issue is how to confront this reality without either blaming the victim (i.e., small farmers as a group) or ignoring the responsibility to improve working conditions (Martin, 2003).

2 This subsection draws on the literature review of Rittenhouse (2011).

\section{Social challenge: Confronting racial and class bias}

One of the most persistent challenges evident in our literature reviews is racial and class bias. At issue is the degree to which relocalization reinforces or exacerbates existing racial and class bias in society, rather than challenging or transforming existing race/class relations. Proponents of community food system initiatives are susceptible to the criticism that they are offering only superficial remedies to deeply rooted problems. The same reality is interpreted by others in the literature as doing the best to carve reform alternatives out of the situation at hand and in the context of constraints and limited resources.

\section{Cultural privilege: The tendency of local food efforts to reinforce the pre-existing advantages of white and more privileged populations.}

Racial and class tensions within community food systems initiatives have been framed by some researchers using a sociocultural lens. The issue is whether initiatives led predominantly by white, well-to-do leaders can effectively address the social and cultural concerns and ideas of nonwhite and poor individuals and communities. Some research argues that existing practices and outcomes are reinforcing existing race and class privileges (Guthman, 2011; Hayes-Conroy, 2010). Boule notes, "Many alternative agriculture institutions such as farmers' markets typically fail to focus on racial and economic equality and even those who do ironically must rely on affluent (often White) consumers for their existence (Alkon, 2008b)" (2012, p. 11). At the same time, when they seek to expand healthy food options in low-income communities, community food activists - mostly white and affluent — have been criticized for imposing "elite culinary preferences" of minimally processed, local, and organic food on the rest of the population (Laudan, 2001). Transcending these tensions will not be easy, but applied research can open up new possibilities. For example, a few researchers are documenting how people of color

\footnotetext{
${ }^{3}$ This section draws on literature reviews written by graduate students Marshall (2011), Bradley (2011), and Harris (2011), and a master's thesis written by Boule (2012).
} 
can take ownership of community food initiatives (Ahmadi, 2011; Bonacich \& Alimahomed-Wilson, 2011; Patel, 2011).

Boule (2012) argues that by focusing primarily on legitimate concerns about financial and physical access to food, alternative food movements do not give adequate attention to how sociocultural issues affect access. She draws on a variety of sources (Green \& Kleiner, 2011; Johnston \& Baumann, 2010; Norgaard, Reed, \& Van Horn, 2011; Slocum, 2006,2008 ) to show how aspects of the dominant white culture often limit the success of community food security initiatives. A deeper understanding of how sociocultural factors come into play in defining and promoting healthy food access is needed. Boule (2012) draws attention to the variety of ways in which everyday people actually define healthy food, often significantly mediated by family, ethnicity, or neighborhood setting. For example, some of her respondents consider a shared family meal using traditional recipes to be healthy, regardless of the nutritional content.

\section{Social distinctions influence how "local" is defined. ${ }^{4}$ Our review suggests there is no clear} agreement on exactly what counts as local food. Some researchers skirt the issue, noting simply that the term "local" is controversial (Cleveland et al., 2011), debatable (Connelly, Markey, \& Roseland, 2011), or lacking in agreed-upon guidelines (Blake, Mellor, \& Crane, 2010). Many definitions of "local" envision a circumference within which food is to be grown and marketed; we find definitions ranging from 50 to 500 miles ( 80 to 800 kilometers), and using existing political boundaries from county to state to nation (Colasanti, Conner, \& Smalleya, 2010; Edwards-Jones et al., 2008).

Interestingly, social distinctions appear to matter in defining local. As Weinberg's (2011) review notes, some definitions of local were centered on social interaction rather than geography. Nurse, Onozaka, \& McFadden (2010) found that definitions changed based on who was doing the defining — consumers or retailers.

\footnotetext{
${ }^{4}$ The discussion of the ambiguous definition of local draws on papers written by graduate students Weinberg (2011) and Pries (2011).
}

Zepeda and Reid (2004), for example, cite a number of local food definitions that were based on methods of harvest like hunting, fishing, and foraging as well as food grown by friends, relatives, and acquaintances. Produce could be considered local, other studies found, if the consumer knew the person who grew it (Milestad, Westberg, Geber, \& Bjorklund, 2010) or even if the produce was delivered by the person who grew it (Bingen, Sage, \& Sirieix, 2011). The presence of different definitions can be instructive since they often imply different ideas about which underlying values are most important. For example, the food miles framing puts the emphasis on ecological concerns surrounding the use of fossil fuels, while for others, the mileage circumference may be less important than whether there is a direct marketing relationship.

\section{Political challenge: Reconciling diverse approaches to creating change}

The literature reveals persistent tradeoffs in forging politically viable change strategies. For example, a common question is whether to pursue an "insider" or "outsider" strategy in making change: emphasizing reform at the margins or more fundamental systemic change (Campbell, 2002). Some advocates work primarily within mainstream institutions in order to encourage incremental adoption of short-term objectives, compromising in the process and risking co-optation. Others seek deeper institutional change or work to build alternative systems that attempt to preserve movement values in their purest forms, even at the cost of short-term gains. Still others suggest that posing the alternatives this starkly is not helpful, instead arguing for middle-ground solutions that weave together these approaches. Finding common ground amidst strategic differences can be challenging, but not impossible (Campbell, 1997, 2002; Stevenson, Ruhf, Lezberg, \& Clancy, 2007). For example, Mendes (2008) shows how an effective food policy council in Vancouver acted as a bridge between inside groups within city bureaucracies and citizens' organizations doing community organizing outside government.

The challenge is to foster a democratic debate that weighs the need to get things done against the 
competing goal of staying true to core values. Allen (2010, p. 297) rightly insists that re-localization of the food and agricultural system will not inherently or inevitably realize values such as social justice or increased equity. On the other hand, neither should local food activists be burdened with the unrealistic expectation that they alone will solve entrenched social dilemmas generated by the current political economy of food and agriculture (Tregear, 2011).

Another way the political strategy question is framed in the literature has to do with the scale at which change strategies are focused. One approach emphasizes a bottom-up approach using local initiative and action to carve out alternatives in light of existing constraints and opportunities (Campbell $\&$ Feenstra, 2001). A more top-down approach emphasizes political and economic reform on broader scales in order to create greater space in which local reform can advance. The skills and proclivities for working at these different scales are distinct, and while some local practitioners have succeeded in aligning themselves with larger coalitions, knitting the two together effectively can be elusive (Sennett, 2012). Even the terminology used to describe food systems, and the assumptions those terms carry, can reinforce stereotypes that may limit creative options. For example, Tregear argues convincingly against the tendency in the literature to set up rigid bifurcations — such as "conventional" and "alternative" — with the result that "existing orthodoxies... are reinforced rather than rethought" (2011, p. 424).

Two examples gleaned from our literature review illustrate how vexing it can be to reconcile diverse change strategies (e.g. insider vs. outsider, reform vs. structural change) and the often strident and ideologically charged debates that arise. These are (1) the controversy over the conventionalization of organics and (2) the recent move to promote values-based supply chains as a key local and regional food system strategy.

Conventionalization of organics. One of the most prominent examples of tension between change strategies in the community food systems literature is the debate over the "conventionalization" of organic food systems (Buck, Getz, \& Guthman, 1997; Guthman, 2004; Rosset \& Alteri,
1997). Before the rise of large-scale organic farms and distribution networks, "organic" was seen by many sustainable agriculture advocates as the true alternative to "conventional." Now, many aspects of organic production, marketing, processing, and distribution practices mimic conventional systems, leading some to question the role organics can and should play in food systems change. While Pollan's discussion of "big organic" in his best-selling The Omnivore's Dilemma (2006) has raised the public profile of this debate, questions began much earlier.

The 1997 article that touched off the debate, by Buck, Getz, and Guthman, claims that organic agriculture has become "conventionalized," moving toward large, mono- or bicropping systems that employ migrant wage labor. The trend has fueled both the explosive growth of organic farms that started out small and the transition of conventional farms and food industries looking to enter the "lucrative, niche" organic market. The authors note that this "conventionalization" was fueled by the passage of the Organic Food Production Act as part of the 1990 farm bill that defined organic in terms of a set of production practices. The social and economic values that may have been included in the organic movement in its early days, including social justice and community economic development, were not advanced in this process. This was especially true, the authors claim, at the marketing and distribution end of the food chain.

Many authors of articles we reviewed analyze the process of conventionalization and its effects (Clark, 2007; Goldberger, 2011; Marsden, Murdoch, \& Morgan, 1999; Thompson \& Coskuner-Balli, 2007). For example, Goldberger's (2011) study reports on a survey conducted with 356 organic farmers in Washington state, finding a range of degrees of conventionalization. While not referencing this debate directly, two articles on organics (Allen \& Kovach, 2000; DuPuis \& Gillon, 2009) go out of their way to argue that organic agriculture still has some power to change the agrofood system. Guptill (2009) suggests there may be some middle ground, noting that family-scale organic dairy producers are responding to conventionalization pressures by seeking out alternative, direct relationships with consumers. 
Organic has been the fastest-growing sector of the food economy for the past two decades, with U.S. sales of organic food and beverages growing from US $\$ 1$ billion in 1990 to US $\$ 26.7$ billion in 2010 (Organic Trade Association, 2011). While contributing to a significant reduction in petrochemical use, these gains have done little to slow the power of transnational companies over food production and distribution across the globe. The mixed results create a situation in which proponents of an insider reform strategy can claim some credit for the scope of the former victory, while proponents of an outsider, fundamental change strategy can lament the lack of progress on deeper structural issues.

Values-based supply chains: Blended alternative and conventional food systems. ${ }^{5}$ Values-based supply chains (VBSCs) are those that aggregate, market, process, and distribute products based on environmental, economic, and social values. Often described as alternative, "these chains are different from traditional supply chains in that they attempt to enhance small and midscale farmers' financial viability by capturing price premiums in the marketplace for the environmental and social benefits (values) embedded in the products" (Feenstra, Allen, Hardesty, Ohmart, \& Perez, 2011, p. 71). This new model for supply chains can offer a range of benefits to farmers, consumers, and food system workers that are not characteristic of the conventional food system as a whole. For example, VBSCs can open up markets for midscale farmers, who often have been left out of burgeoning small-scale, direct-to-consumer markets and for whom commodity markets offer little profit. For consumers some researchers hold out hope that VBSCs can deliver high-quality produce to low-income communities, primarily through institutions like schools and hospitals as well as retail outlets.

At the same time, several researchers have questioned the division between conventional supply chains and VBSCs. These researchers

\footnotetext{
${ }^{5}$ The values based supply chain discussion draws on papers written by graduate students O'Sullivan (2011) and Lerman (2011).
}

describe VBSCs as what they are calling "hybrid food chains" (Bloom \& Hinrichs, 2011a; Clancy \& Ruhf, 2010), which share infrastructure and markets with conventional firms while moving produce with "alternative" values. Both conventional and VBSCs are driven and limited by the same factors that determine success in the market, including price, efficiency, food safety, and convenience (Feenstra et al., 2011). Whether alternative values will be sacrificed in serving these conventional priorities remains a key concern. There is disagreement in the literature about whether VBSCs are a type of shallow reform or a genuine alternative. Citing pragmatism, some authors argue that local supply chains cannot develop without the use of the conventional food system infrastructure and markets (King et al., 2010). Others warn that VBSCs constructed in this way will reproduce the social inequities that they sought to reform (Trauger, 2009) and, worse still, they will co-opt the market for values-based food and mask injustice in their supply chains (Bloom \& Hinrichs, 2011b). The debates surrounding organics and VBSCs highlight the interconnections between conventional and alternative food systems, suggesting that for some purposes it is not useful to view them as two separate systems at all.

\section{Toward a Research Agenda To Inform Community Food Systems Practice}

Local actors with diverse goals and motivations are pursuing work that has the potential to advance goals and values associated with community food systems. Aided by a new tool - a community food systems bibliography - our partial review of the literature in the field suggests a set of persistent and interrelated strategic challenges that pose tradeoffs among competing values and priorities. Rooted in some of the longest-standing social structures, from the capitalist marketplace to persistent racial and class tensions, these challenges defy simple or ready resolution, and do not lend themselves to tidy lists of best practices. Instead, they call for strategic thinking to resolve tensions and tradeoffs in context-specific settings via ongoing experimentation, contestation, compromise, and working accommodation. Viable options must be carved out of the situation at hand using 
existing resources and against the backdrop of mainstream institutions that alternatively embrace, resist, or refashion specific reforms (Hess, 2007). At issue for the field as this process of incorporation and transformation proceeds: How can researchers and practitioners join forces to promote the kind of learning needed to advance this work?

Our research suggests one approach that may be particularly fruitful. The three strategic challenges identified in our partial review of the literature, and others that might surface in future reviews by our team or others, provide a set of reference points by which one might compare and learn from the distinct problem-solving activities of local reformers working in different settings. By designing comparative case studies focused on how the challenges are being addressed in distinct community settings, or by mining existing case studies in the literature using meta-analytic techniques (Hodson, 2001), we can create empirically informed theory that helps guide practice. It may be particularly useful to craft new applied studies with a developmental lens and with the active participation of people working on the ground. The developmental perspective is particularly useful in situations where there is not a clear set of procedures for moving forward that can be specified in advance (Patton, 2010). Instead, innovations might be pursued through a succession of experiments from which participants in the process attempt to learn what needs to be done.

Applied research in this fashion is not completely open-ended, however, since it can build on some general and well-established ideas from the fields of community development and public policy about what it takes to build a successful community change coalition. These include:

- clarity of purpose and focus: articulating overall community-scale change objectives with broad appeal while also establishing concrete priorities that compel the attention of taskspecific groups (Gardner, 2005; Stone, Orr, \& Worgs, 2006);

- community legitimacy: broad and inclusive membership that is sustained over time (Flora, Sharp, Flora, \& Newlon, 1997);
- mobilization of resources: tapping and expanding existing networks such that partners are contributing their own resources to the larger effort, and resources are strategically realigned to support coalition goals (Gardner, 2005; Kubisch, 2005);

- policy development: a strategy targeting particular policies or systems to change and particular constituencies to mobilize (Kubisch, 2005; Stone et al., 2006); and

- institutional embeddedness and transparency: anchoring the work in some form of organizational home with skilled staff and clear, inclusive decision-making processes (Flora et al., 1997; Stone et al., 2006).

Three examples can be noted to indicate the types of practice-oriented research we have in mind. First, Boyte and Kari's (1996) theory of public work is a useful conceptual framework to guide comparative case studies. It focuses particularly on examining what it takes to bring together diverse groups (in terms of race, class, etc.) with divergent interests in order to build, in common, things of public value. Drawing on this framework, Peters, Jordan, Adamek, \& Alter (2005) have compared cases where land grant university researchers have partnered with local communities around food system projects. Their exploration of the concept and practice of "public scholarship" through case studies at eight land grant and state universities shows how academics and community practitioners can support each other in building community food system initiatives.

Second, comparative case studies might fruitfully use the community capitals framework (Emery \& Flora, 2006) to deepen insight. For example, researchers at Virginia Tech and North Carolina State have used community capitals to compare the development of community food systems at a variety of locations across Virginia and North Carolina. ${ }^{6}$ Their case studies examine how local food activists mobilize various forms of capital — social, political, financial, human, etc. to realize the values of equity, justice, sustainability,

\footnotetext{
${ }^{6}$ For information on this ongoing project, see: http://www.cfse.ext.vt.edu/index.php/about-cfse
} 
and democracy in the face of challenges such as those we have described. For example, do communities spend most of their political capital on local battles or attempt to balance that with engaging national or international issues? Is the approach to political engagement weighted toward insider or outsider strategies, and what effect does this have on their ability to access public or private funding support? A wide range of important questions such as these flow from using the capitals framework and would be ideally suited to shaping comparative case study research.

Third, it will be useful to view community food system challenges within the framework of community governance and planning (Campbell, 2004; Stone et al., 2006). For example, Mendes (2008) shows how a focus on local governance capacity can help answer the question of why sustainability policies around food take deeper root in some settings than others. Key variables identified in her research include both structural variables ("legal status and mandated role; staffing support; integration of food policy into normative and legal frameworks") and procedural factors ("involvement of joint-actor partnerships and networks in planning and policy making; citizen participation mechanisms including marginalized populations") (Mendes, 2008, p. 951). A more extensive set of case histories - with appropriate attention paid to particular local dynamics and unique circumstances - might provide a range of lessons to inform how other communities confront a number of vexing questions. These include: Which local food strategies require institutionalization and which do not? How to garner the resources of institutions without losing the sense of community ownership? How to take advantage of the space for local experimentation while remaining cognizant of how local governments often serve entrenched interests?

Whatever conceptual frameworks are used, practitioners need to be active partners in advancing and generating new knowledge. This might include putting greater priority on fostering partnerships between practitioners and researchers to design and implement research projects on identified challenges. Funders need to be part of this dialog as well, in part because they often approach research solely through the lens of evaluation, and in ways that discourage honest appraisal by grantees hoping to remain in good favor. If organizations could build relationships with funders where they are rewarded for being in partnership with researchers, no matter the outcome of the research, we might see more progress on some of the deeper challenges we have identified.

With each year, even each month, that passes, the body of research on community food systems grows. We have shown how a comprehensive community food systems bibliography can be a useful tool for identifying key challenges in the field, and argued for how research might be better conceived and analyzed in order to create insights that can shape and guide practice. We hope others will use and improve upon the community food systems bibliography we have compiled to further this goal. Together we can foster a conversation about community food systems in which research and practice are mutually reinforcing.

\section{Acknowledgments}

The research involves a multiyear collaboration among University of California, Davis faculty and students, under the leadership of David Campbell, Gail Feenstra, and Ryan Galt. Key graduate student collaborators to date include Courtney Marshall, Ildi Carlisle-Cummins, and Michael Weinberg. Marshall's work compiling the Community Food Systems bibliography was particularly instrumental in launching the project. Literature reviews produced by graduate students in a fall 2011 seminar made important contributions to this paper. The students included Katharine Bradley, Ildi CarlisleCummins, Anna Goldberg, Sheila Golden, Therese Harris, Tracy Lerman, Courtney Marshall, Karyn Medina, Shaina Meiners, Elizabeth O'Sullivan, Sean Pries, Thea Rittenhouse, Maria Elena Rodriguez, Alberto Valdivia, and Michael Weinberg.

\section{References}

Ahmadi, B. (2011). Racism and Food Justice: The Case of Oakland. In E. Holt-Gimenez (Ed.), Food movements unite! (pp. 149-162). Oakland, California: Food First Books. 
Algert, S. J., Agrawal, A., \& Lewis, D. S. (2006). Disparities in access to fresh produce in lowincome neighborhoods in Los Angeles. American Journal of Preventive Medicine, 30(5), 365-370. http://dx.doi.org/10.1016/j.amepre.2006.01.009

Alkon, A. H. (2008a). From value to values: Sustainable consumption at farmers markets. Agriculture and Human Values, 25(4), 487-498. http://dx.doi.org/10.1007/s10460-008-9136-y

Alkon, A. H. (2008b). Paradise or pavement: The social constructions of the environment in two urban farmers' markets and their implications for environmental justice and sustainability. Local Environment, 13(3), 271-289. http://dx.doi.org/10.1080/13549830701669039

Allen, P. (1999). Reweaving the food security safety net: Mediating entitlement and entrepreneurship. Agriculture and Human V alues, 16(2), 117-129. http://dx.doi.org/10.1023/A:1007593210496

Allen, P. (2010). Realizing justice in local food systems. Cambridge Journal of Regions, Economy and Society, 3(2), 295-308. http://dx.doi.org/10.1093/cjres/rsq015

Allen, P., \& Kovach, M. (2000). The capitalist composition of organic: The potential of markets in fulfilling the promise of organic agriculture. Agriculture and Human Values, 17(3), 221-232. http://dx.doi.org/10.1023/A:1007640506965

Baker, L. (2003). Tending cultural landscapes and food citizenship in Toronto's community gardens. Geographical Review, 94(3), 305-325. http://dx.doi.org/10.1111/j.19310846.2004.tb00175.x

Bingen, J., Sage, J., \& Sirieix, L. (2011). Consumer coping strategies: a study of consumers committed to eating local. International Journal of Consumer Studies, 35(4), 410-419. http://dx.doi.org/10.1111/j.14706431.2010.00949.x

Blake, M. K., Mellor, J., \& Crane, L. (2010). Buying local food: shopping practices, place, and consumption networks in defining food as "local." Annals of the Association of American Geographers, 100(2), 409-426. http://dx.doi.org/10.1080/00045601003595545

Block, D., \& Kouba, J. (2006). A comparison of the availability and affordability of a market basket in two communities in the Chicago area. Public Health Nutrition, 9(7), 837-845. http://dx.doi.org/10.1017/PHN2005924
Bloom, J. D., \& Hinrichs, C. C. (2011a). Informal and formal mechanisms of coordination in hybrid food value chains. Journal of Agriculture, Food Systems, and Community Development, 1(4), 1-14. http://dx.doi.org/10.5304/jafscd.2011.014.016

Bloom, J. D., \& Hinrichs, C. C. (2011b). Moving local food through conventional food system infrastructure: Value chain framework comparisons and insights. Renewable Agriculture and Food Systems, 26(1), 13-23.

Bonacich, E., \& Alimahomed-Wilson, J. (2011). Confronting racism, capitalism, and ecological degradation: Urban farming and the struggle for social justice in Black Los Angeles. Souls: A Critical Journal of Black Politics, Culture, and Society, 13(2), 213-226.

Boule, D. (2012). Beyond black and white: Understanding the cultural dimensions of healthy food access in South Sacramento (Unpublished master's thesis). Department of Community Development, University of California Davis, Davis, California.

Boyte, H. C., \& Kari, N. N. (1996). Building America: The democratic promise of public work. Philadelphia: Temple University Press.

Bradley, K. L. (2011). A literature review on the intersection of race and food justice (Unpublished class paper, CRD 298, Community Food Systems, Fall 2011). Department of Human and Community Development, University of California Davis.

Buck, D., Getz, C., \& Guthman, J. (1997). From farm to table: The organic vegetable commodity chain of Northern California. Sociologia Ruralis, 37(1), 3-20. http://dx.doi.org/10.1111/1467-9523.00033

Campbell, D. (1997). Community-controlled economic development as a strategic vision for the sustainable agriculture movement. American Journal of Alternative Agriculture, 12(1), 37-44. http://dx.doi.org/10.1017/S0889189300007177

Campbell, D. (2002). Conviction seeking efficacy: Sustainable agriculture and the politics of cooptation. Agriculture and Human Values, 18(4), 353363. http://dx.doi.org/10.1023/A:1015210215751

Campbell, D., \& Feenstra, G. (2001). A local partnership for sustainable food and agriculture: The case of PlacerGROWN. In M. R. Daniels (Ed.), Creating Sustainable Community Programs: Examples of Collaborative Public Administration (pp. 205-220). Westport, Connecticut: Praeger. 
Campbell, M. C. (2004). Building a common table: The role for planning in community food systems. Journal of Planning Education and Research, 23(4), 341-355. http://dx.doi.org/10.1177/0739456X04264916

Clancy, K., \& Ruhf, K. (2010). Is local enough? Some arguments for regional food systems. Choices, 25(1).

Clark, L.F. (2007). Business as usual? Corporatization and the changing role of social reproduction in the organic agrofood sector. Studies in Political Economy, $80,55-74$.

Cleveland, D. A., Radka, C. N., Muller, N. M., Watson, T. D., Rekstein, N. J., Wright, H. V., \& Hollingshead, S. E. (2011). Effect of localizing fruit and vegetable consumption on greenhouse gas emissions and nutrition, Santa Barbara County. Environmental Science \&o Technology, 45(10), 45554562. http://dx.doi.org/10.1021/es1040317

Colasanti, K. J. A., Conner, D. S., \& Smalleya, S. B. (2010). Understanding barriers to farmers' market patronage in Michigan: Perspectives from marginalized populations. Journal of Hunger \& Environmental Nutrition, 5(3), 316-338. http://dx.doi.org/10.1080/19320248.2010.504097

Connelly, S., Markey, S., \& Roseland, M. (2011). Bridging sustainability and the social economy: Achieving community transformation through local food initiatives. Critical Social Policy, 31(2), 308-324. http://dx.doi.org/10.1177/0261018310396040

DuPuis, E. M., \& Gillon, S. (2009). Alternative modes of governance: Organic as civic engagement. Agriculture and Human Values, 26(1-2), 43-56. http://dx.doi.org/10.1007/s10460-008-9180-7

Edwards-Jones, G., Milá i Canals, L., Hounsome, N., Truniger, M., Koerber, G., Hounsome, B., Jones, D. L. (2008). Testing the assertion that "local food" is best: The challenges of an evidence-based approach. Trends in Food Science and Technology, 19(5), 265-274.

http://dx.doi.org/10.1016/i.tifs.2008.01.008

Emery, M., \& Flora, C. (2006). Spiraling-up: Mapping community transformation with the community capitals framework. Community Development, 37, 1935. http://dx.doi.org/10.1080/15575330609490152

Feenstra, G. (2002). Creating space for sustainable food systems: Lessons from the field. Agriculture and Human Values, 19(2), 99-106. http://dx.doi.org/10.1023/A:1016095421310
Feenstra, G., Allen, P., Hardesty, S., Ohmart, J., \& Perez, J. (2011). Using a supply chain analysis to assess the sustainability of farm-to-institution programs. Journal of Agriculture, Food Systems, and Community Development, 1(4), 69-84. http://dx.doi.org/10.5304/jafscd.2011.014.009

Flora, J. L., Sharp, J., Flora, C., \& Newlon, B. (1997). Entrepreneurial social infrastructure and locally initiatied economic development in the nonmetropolitan United States. Sociological Quarterly, 38, 623-645. http://dx.doi.org/10.1111/j.15338525.1997.tb00757.x

Food Chain Alliance. (2012, June). The hand that feeds us: Challenges and opportunities for workers along the food chain (Food Chain Alliance, Trans.). Los Angeles: Author.

Gardner, S. L. (2005). Cities, counties, kids and families: The essential role of local government. Lanham, Maryland: University Press of America.

Goldberger, J. R. (2011). Conventionalization, civic engagement, and the sustainability of organic agriculture. Journal of Rural Studies, 27(3), 288-296. http://dx.doi.org/10.1016/j.jrurstud.2011.03.002

Grace, C., Grace, T., Becker, N., Lyden, J. (2008). Barriers to using urban farmers' markets: An investigation of food stamp clients' perception. Journal of Hunger \& Environmental Nutrition, 2(1), 5575. http://dx.doi.org/10.1080/19320240802080916

Green, J. J., \& Kleiner, A. M. (2011). Past to the present: Agricultural development and black farmers in the American South. In A. H. Alkon \& J. Agyeman (Eds.), Cultivating food justice: Race, class and sustainability (pp. 47-64). Cambridge, Massachusetts: The MIT Press.

Guptill, A. (2009). Exploring the conventionalization of organic dairy: Trends and counter-trends in upstate New York. Agriculture and Human V alues, 26(1-2), 29-42. http://dx.doi.org/10.1007/s10460-0089179-0

Guthman, J. (2004). The trouble with "organic lite" in California: A rejoinder to the "conventionalisation" debate. Sociologia Ruralis, 44(3), 301-316. http://dx.doi.org/10.1111/j.1467-9523.2004. 00277.x

Guthman, J. (2011). "If they only knew." The unbearable whiteness of alternative food. In A. H. Alkon \& J. Agyeman (Eds.), Cultivating Food Justice: Race, Class and Sustainability (pp. 263-281). Cambridge, Massachusetts: The MIT Press. 
Guthman, J., Morris, A. W., \& Allen, P. (2006). Squaring farm security and food security in two types of alternative food institutions. Rural Sociology, 71(4), 662-684. http://dx.doi.org/10.1526/003601106781262034

Harris, T. (2011). Overview of literature on food justice/ food access. (Unpublished class paper, CRD 298, Community Food Systems, Fall 2011). Department of Human and Community Development, University of California Davis.

Hayes-Conroy, A. (2010). Feeling Slow Food: Visceral fieldwork and empathetic research relations in the alternative food movement. Geoforum, 41(5), 734-742. http://dx.doi.org/10.1016/j.geoforum.2010.04.005

Hess, D. J. (2007). Alternative pathways in science and industry: Activism, innovation, and the environment in an era of globalization. Cambridge, Massachusetts: MIT Press.

Hinrichs, C. C., \& Allen, P. (2008). Selective patronage and social justice: Local food consumer campaigns in historical context. Journal of Agricultural and Environmental Ethics, 21(4), 329-352. http://dx.doi.org/10.1007/s10806-008-9089-6

Hodson, R. (2001). Dignity at work. Cambridge: Cambridge University Press.

Johnston, J., \& Baker, L. (2005). Eating outside the box: FoodShare's Good Food Box and the challenge of scale. Agriculture and Human Values, 22(3), 313-325. http://dx.doi.org/10.1007/s10460-005-6048-y

Johnston, J., \& Baumann, S. (2010). Foodies: Democracy and distinction in the gourmet foodscape. New York: Routledge.

King, R. P, Hand, M. S., DiGiacomo, G., Clancy, K., Gómez, M. I., Hardesty, S. D., \& McLaughlin, E. W. (2010). Comparing the structure, size, and performance of local and mainstream food supply chains (Report No. ERR-99). Washington, D.C.: United States Department of Agriculture, Economic Research Service. Retrieved from http://www.ers.usda.gov/publications/err99/

Kubisch, A. C. (2005). Comprehensive community building initiatives - ten years later: What we have learned about the principles guiding the work. New Directions for Youth Development, 106, 17-26. http://dx.doi.org/10.1002/yd.115
Laudan, R. (2001). A plea for culinary modernism. Gastronomica, 36-43. http://dx.doi.org/10.1525/gfc.2001.1.1.36

Lautenschlager, L., \& Smith, C. (2007). Beliefs, knowledge, and values held by inner-city youth about gardening, nutrition, and cooking. Agriculture and Human V alues, 24(2), 245-258.

Lerman, T. (2011). V alues-based supply chains literature review (Unpublished class paper, CRD 298, Community Food Systems, Fall 2011). Department of Human and Community Development, University of California Davis.

Marsden, T., Murdoch, J., \& Morgan, K. (1999). Sustainable agriculture, food supply chains and regional development. International Planning Studies, 4(3), 295-301. http://dx.doi.org/10.1080/13563479908721743

Marshall, C. (2011). Community food security/food justice (Unpublished class paper, CRD 298, Community Food Systems, Fall 2011). Department of Human and Community Development, University of California Davis.

Martin, P. (2003). Promise unfulfilled: Unions, immigration, and farm workers. Ithaca, New York: Cornell University Press.

McEntee, J. (2010). Contemporary and traditional localism: A conceptualisation of rural local food. Local Environment: The International Journal of Justice and Sustainability, 15(9-10), 785-803.

Meehan, M., Yeh, M.C., \& Spark, A. (2008). Impact of exposure to local food sources and food preparation skills on nutritional attitudes and food choices among urban minority youth. Journal of Hunger \& Environmental Nutrition, 3(4), 456-471. http://dx.doi.org/10.1080/19320240802529383

Mendes, W. (2008). Implementing social and environmental policies in cities: The case of food policy in Vancouver, Canada. International Journal of Urban and Regional Research, 32(4), 942-967. http://dx.doi.org/10.1111/j.1468-2427.2008. 00814.x

Milestad, R., Westberg, L., Geber, U., \& Bjorklund, J. (2010). Enhancing adaptive capacity in food systems: Learning at farmers' markets in Sweden. Ecology and Society, 15(3), 29-47. 
Munoz-Plaza, C. E., Filomena, S., \& Morland, K. B. (2008). Disparities in food access: Inner-city residents describe their local food environment. Journal of Hunger \& Environmental Nutrition, 2(2), 5164. http://dx.doi.org/10.1080/19320240801891453

Murphy, J., \& Smith, S. (2009). Chefs and suppliers: An exploratory look at supply chain issues in an upscale restaurant alliance. International Journal of Hospitality Management, 28(2), 212-220. http://dx.doi.org/10.1016/i.ijhm.2008.07.003

Norgaard, K. M., Reed, R., \& Van Horn, C. (2011). A continuing legacy: Institutional racism, hunger and nutritional justice on the Klamath. In A. Alkon \& J. Agyeman (Eds.), Cultivating Food Justice: Race, Class and Sustainability (pp. 23-46 ). Cambridge, Massachusetts: The MIT Press.

Nurse, G., Onozaka, Y., \& McFadden, D. T. (2010, February 6-9). Understanding the connections between consumer motivations and buying behavior: The case of the local food system movement. Paper presented at the Southern Agricultural Economics Association Annual Meeting, Orlando, Florida.

Ohri-Vachaspati, P., Masi, B., Taggart, M., Konen, J., \& Kerrigan, J. (2009). City Fresh: A local collaboration for food equity. Journal of Extension, 47(6).

Organic Trade Association. (2011). Organic Trade Association industry survey. Retrieved from http://www.ota.com/organic/mt/business.html

O'Sullivan, L. (2011). Literature review on values-based supply chains/alternative food networks (Unpublished class paper, CRD 298, Community Food Systems, Fall 2011). Department of Human and Community Development, University of California Davis.

Patel, R. (2011). Survival pending revolution: What the Black Panther Party can teach the U.S. Food movement. In E. Holt-Giménez (Ed.), Food Movements Unite! (pp. 115-135). Oakland, California: Food First Books.

Patton, M. Q. (2010). Developmental evaluation: Applying complexity concepts to enhance innovation and use. New York: Guilford Press.

Peters, S. J., Jordan, N., Adamek, M., \& Alter, T. (2005). Engaging campus and community: The practice of public scholarship in the state and land grant university system. Dayton, Ohio: The Kettering Foundation.

Pollan, M. (2006). The omnivore's dilemma: A natural bistory of four meals. New York: Penguin Press.
Pries, S. (2011). Literature review on local food systems and the environment (Unpublished class paper, CRD 298, Community Food Systems, Fall 2011). Department of Human and Community Development, University of California Davis.

Rittenhouse, T. (2011). The inclusion of farm labor practices in the context of community food systems: Literature review (Unpublished class paper, CRD 298, Community Food Systems, Fall 2011). Department of Human and Community Development, University of California Davis.

Rosset, P. M., \& Altieri, M. A. (1997). Agroecology versus input substitution: A fundamental contradiction of sustainable agriculture. Society \& Natural Resources, 10(3), 283-295. http://dx.doi.org/10.1080/08941929709381027

Seligman, H. K., \& Schillinger, B. (2010). Hunger and socioeconomic disparities in chronic disease. New England Journal of Medicine, 363, 6-9. http://dx.doi.org/10.1056/NEJMp1000072

Sennett, R. (2012). Together: The rituals, pleasure and politics of cooperation. New Haven: Yale University Press.

Shreck, A., Getz, C., \& Feenstra, G. (2006). Social sustainability, farm labor, and organic agriculture: Findings from an exploratory analysis. Agriculture and Human Values, 23(4), 439-449. http://dx.doi.org/10.1007/s10460-006-9016-2

Slocum, R. (2006). Anti-racist practice and the work of community food organizations. Antipode, 38(2), 327-347. http://dx.doi.org/10.1111/j.1467$\underline{8330.2006 .00582 . x}$

Slocum, R. (2008). Thinking race through corporeal feminist theory: Divisions and intimacies at the Minneapolis Farmers' Market. Social and Cultural Geography, 9(8), 849-869. http://dx.doi.org/10.1080/14649360802441465

Stevenson, G. W., Ruhf, K., Lezberg, S., \& Clancy, K. (2007). Warrior, builder, and weaver work: Strategies for changing the food system. In C. C. Hinrichs \& T. A. Lyson (Eds.), Remaking the North American food system: Strategies for sustainability (pp. 3364). Lincoln, Nebraska: University of Nebraska Press.

Stone, C., Orr., M., \& Worgs, D. (2006). The flight of the bumblebee: Why reform is difficult but not impossible. Perspectives on Politics, 4, 529-546. http://dx.doi.org/10.1017/S1537592706060348 
Thompson, C. J., \& Coskuner-Balli, G. (2007). Countervailing market responses to corporate co-optation and the ideological recruitment of consumption communities. Journal of Consumer Research, 34(2), 135-152. http://dx.doi.org/10.1086/519143

Trauger, A. (2009). Social agency and networked spatial relations in sustainable agriculture. Area, 41(2), 117128. http://dx.doi.org/10.1111/j.1475-4762.2008. 00866.x

Tregear, A. (2011). Progressing knowledge in alternative and local food networks: Critical reflections and a research agenda. Journal of Rural Studies, 27, 419-430. http://dx.doi.org/10.1016/i.jrurstud.2011.06.003

Weinberg, M. (2011). Consumer preference and demand for local food (Unpublished class paper, CRD 298, Community Food Systems, Fall 2011). Department of Human and Community Development, University of California Davis.

Zepeda, L., \& Leviten-Reid, C. (2004). Consumers views on local food. Journal of Food Distribution Reseach, 35(3), 1-6. 